This article has been scanned by iThenticat No plagiarism detected

Volume 3, Issue 4, August 2021

p. $95-100$

\title{
THE DIGITAL TRANSFORMATION CHALLENGES IN HIGHER EDUCATION INSTITUTION IN PALESTINE DURING THE COVID-19 CRISIS
}

http://dx.doi.org/10.47832/2757-5403.4-3.8

\section{Yasmeen ABU MUKH ${ }^{1}$ \& Reham SALHAB ${ }^{2}$}

\begin{abstract}
:
This article aims to shed the light on challenges that Palestinian university faced during COVID-19 pandemic. The technology and the digital environment are becoming part of our lifestyle. The whole world has been asked to change the way we work and live during COVID-19 pandemic. No more students sit in the classroom and listen only to lectures these days. Nowadays, education is interactive and engaging. Teachers are doing their best to approach instruction with technology being the mediator in the classroom. Digital transformation is a fundamental process in the knowledge society where information technologies play a vital role in helping students to produce knowledge and process information to meet the ever-growing demands of students, faculty and campus to create a learning environment where everything connects, therefore the efforts of universities, especially arab universities, began to digitize the learning process. As a result of this education Palestine universities has transformed into a rapid, and simple digital education, as the COVID-19 system resulted in the rise of e-learning on an unprecedented scale. Some challenges presented like: lack of strategic plan, digital inequity, technology infrastructure. We recommended the presence of instructional designers and the necessity of the continues evaluation process.
\end{abstract}

Key words: Digital Transformation; Higher Education, Challenges.

\footnotetext{
${ }^{1}$ Researcher, An-Najah National University, Palestine, yasmeena 26@hotmail.com, https://orcid.org/00000001-9367-2452

${ }^{2}$ Researcher, An-Najah National University, Palestine, reham salhab@hotmail.com, https://orcid.org/0000$\underline{0002-3457-389 X}$
}

Copyright (C) Published by IJHER Journal, www.ijherjournal.com Rimar Academy, Fatih, Istanbul, 34093 Turkey

All rights reserved 


\section{Introduction}

The global COVID-19 pandemic and the massive university closings that have taken place in response to it have, for better or worse, given educators in higher education throughout the world a proverbial kick in the rear-end, sending us headlong into the 21 st century, no matter how ill-prepared we may have been, and notwithstanding the significant pedagogical limitations and socioeconomic inequalities that have marked distance learning efforts. No matter what our qualms or reservations, and the extent to which learners participate in the educational process a digital transformation and digital revolution in higher education can no longer be dismissed or deferred. Indeed, the present crisis may very well embody a golden opportunity that promises to accelerate essential and long overdue processes of momentous change. Yet, given the undeniable failures of the last several months (Hobbs \& Hawkins, 2020; Herold, 2020), questions concerning how digital learning can be implemented in a manner that is pedagogically effective, intellectually challenging, conducive to creativity (Loveless et al., 2006), open and inclusive, viable on a practical and logistic level, compatible with democratic values, and respectful of human privacy and dignity remain more relevant than ever.

\section{Digital transformation}

Digital transformation is the significant physical and philosophical factor in technological evolution, which allows service providers to overcome the territorial constraints, reduce transaction costs for decision making and bargaining, and develop new business models based on networking effects which offer service to faculty, and campus as a whole (Emilio, 2020).

\section{Higher education in Palestine}

It is important to emphasize in this context that, higher education in particular in Palestine has been subjected in recent decades, the development of online learning as a replacement for face-to-face learning is the most efficient and cost-effective method to continue learning and should be part of a school's overall crisis response protocol (Bozkurt \& Sharma, 2020). In this context not only has it become more difficult for instructors, but for students as well (Rapanta, et al., 2020).

\section{The digital transformation in higher education}

In the present health emergency, higher education institutions have taken up digital learning across the board in many cases, and there was a 'risk mitigation' measure (Devaney et al., 2020) to sustain education in the face of looming disaster. This shift in and of itself is significant, but it is too early to say what it augurs precisely for the future of higher education and its traditional emphasis on the face-to-face encounter, particularly in those fields of study, more specifically in the fray of buying and selling 'knowledge' as a commodity, in which distance learning, cannot hope to provide an adequate substitute or compensate for the physical experience or 'touch' element, such as the visual and performing arts, archaeology, the health sciences. Moreover, online learning holds little of the allure of campus life, and the important personal relationships and social connections that emerge from it, by which institutions traditionally justify tuition fees, and for which students are willing to plunge themselves into eternal debt (DePietro, 2020). Nor does it offer such simple tactile pleasures as turning the pages of a leather-bound book in a woodpaneled library. Beyond this are the ethical and privacy concerns regarding the ownership and use of the countless caches of information generated by student interactions with digital media, as well as the social ramifications of remote learning as a new norm. None of the issues involved have easy answers, but it is important to remember, as Sofer (2020) suggests, that "technology is neither good nor bad; its use can be either bad or good from a normative standpoint. These times have opened up a significant aperture. If [ digital Transformation] places the student at the center and makes higher education more accessible to wider publics, including those excluded today, so be it. For this to happen, the digital divide that still exists in Palestine society as in the world at large must vanish as part of broader social processes. Otherwise, digital learning will merely perpetuate disparities rather than contribute to their eradication." 
Virtual learning undoubtedly as a result of the digital transformation is replete with paradoxes. For both as a pedagogue and a student, is the fact that while the online learning environment renders geophysical limits irrelevant by allowing instantaneous academic collaboration and knowledge-sharing between participants regardless of their physical location, and by enabling participants to conduct their domestic and academic lives simultaneously, even potentially dissolving certain center-periphery distinctions, the collapse of boundaries between university and home more often than not actually seems to undermine the learning process (Zalmanson, 2020). This is because, as Zalmanson (2020) notes, "the moment the academic institution is a part of the student's home environment, he is bound to experience difficulty distinguishing between home and the learning situation. This lack of distinction is liable to cause the student attention and concentration difficulties, minimize the unmediated social experience that is one of the advantages of the academic framework, and turn the lesson into just another open screen between the computer game and YouTube, just another snippet of information in our lives." This antimony is only one of the challenges we all must grapple with as digital learning becomes the dominant paradigm in education in the months and years ahead, as the current pandemic and anticipation of future pandemics redefine the educational institution's mandates, mindsets and methodologies. In the end, all of us in academia must come to terms with, and prepare ourselves as best we can for, a "digital transformation in university education" (Kaminskyi et al., 2018) that assumes one form or another.

\section{The challenges of digital transformation under the COVID-19}

David et al. (2020) note four key constraints of digital transformation that affect the transition to remote learning under the COVID-19 crisis: (1) weak education management and data collection systems, (2) a slowing of "students' progression against formal curriculums", (3) profound variance in “"teachers' ability to adapt to delivering education, and evaluation of students with credibility and confidence and implementation of online Teaching." and (4) a lack of access among many "to technology or a suitable learning environment at home" (pp. 2-4). Undeniably, it is hard understand how a genuinely inclusive digital transformation in education can be realized, now or in the future, without at the very least guaranteeing, as recommended by the United Nations, universal cost-free high-speed internet access as a fundamental human right (McHugh, 2011). Indeed, as long as a 'digital divide' exists in which internet and mobile access varies drastically across socioeconomic groups (Hilbert, 2011), and may be denied entirely to certain marginalized communities, the learning gap the present crisis has put into unsettling relief cannot be bridged. Nowhere is this problem more acute than in Palestine, where the technology infrastructure is still not well prepared.

\section{Challenges of digital transformations in Palestine}

Digital transformation in Palestine was is still not clearly visible. It is still struggling to make transition towards a dynamic skills-based society, but is improving gradually. Generally, Palestinian universities perceive digital transformation as a technological tool and cannot internalize their corporate goals as a strategic component. The emphasis on integrating technology tools is limited to using educational videos, emails, computerized tests, and posting instructional materials on LMS with no interaction (Shraim \& Crompton, 2020).

Palestine has switched to technology and online teaching during COVID-19 lockdown that gave a great opportunity for universities and institutions of higher education to make a rapid shift to digital learning and implementing online classes, online workshops, online conferences, online panel discussions and millions of webinars that have been conducted during the last year. This transformation gave a clear signal of rapid change in educational space and the role of digital learning that shall play to improve the quality and relevance of education from here after.

Many universities did a great job with the emergency plan, they followed plans as assigned by university e-learning departments as academics, even with the absence of a national strategy with clear vision and mission towards this digital transition. They started to use LMS on regular basis with some guidance from the e-learning department, synchronous and asynchronous meetings were mandatory, activities, weekly assignments and summative assessment tools were implemented. Some challenges presented during the implementation of this plan: 
No clear strategic plan was available that outlines long-term strategic goals for digital transformation, they only have a phased path for gradual implementation that did not take into consideration several factors that include: human, institution, technology, and the online environment.

Lack of vision and goals, academic staff want to text; they want to email; they want to contact more; they want to contact less.... A lack of coordinated vision in my university prohibited full digital transformation.

Technology infrastructure was not well established due to this lack of strategic plans.

Professional identity of academic staff started to improve and changed as a result of this shift towards digitization of teaching. Moreover, pedagogical content was not well designed, lack of coordination and collaborative and personalized learning were not implemented properly due to insufficient academic staff digital skills. Also, lack of communication across the entire organization, our university is implementing a new technology and encouraging everyone to embrace it, employee resistance presented at the beginning because of their lack of competencies and skills needed for this transformation. Honestly, the technology support department has led the process professionally with weekly plans into digital transformation, but still there was lack of communication. Another critical issue was the quality of the digital content (content model), which was lower than the quality of face-to-face and normal online learning. Moreover, instructional designers were needed for this matter, since teachers do not have time to design the activities and evaluation tools. Moreover, digital privacy was a great challenge as well, many students have complained that sharing devices such as smartphones, laptops, or desktops are considered as a violation of individual privacy. Another challenge was female students reported that their teachers asked them to use webcams which they considered as an invasion of their digital privacy (Khlaif, \& Salha, 2020). Some families did not allow their girls to attend online classes because the teacher asked them to share personal information such as their social media accounts and to share their laptop screen. Digital Inequity was a challenge too, unfair resource distribution among students, technical knowledge and skills vary between students, and the impact of ICT use (Yuen, Park, Chen, Cheng, 2018). Students struggled with digital equity, digital ethics and accessibility of educational resources delivered by LMS. Learners needs was another challenge; it is important to emphasize that a great diversity of profiles, it was not easy to identify learners' needs and styles without previous planning. It was not easy to privilege a particular pedagogical model, instead it is very important to design learning environments that take learners' needs and the context into account. Providing formative, timely, and individualized feedback has also been identified as an important challenge in the online learning environment. Likewise, more recent studies have also highlighted the importance of timely, formative, effective, and individualized feedback in order to efficiently support learning (Gros, García-Peñalvo, 2016).

Academics competencies, academics are expected to gain new merits such as to be able to use technology creatively, to adapt education standards to 21 st century knowledge and skills, to develop project-oriented teaching methods, project based learning, to use new and modern strategies in student performance evaluation and assessment, to implement personalized and massive learning strategies, to apply differentiated educational programs and adopt flexible learning (Affouneh, Salha, Khlaif, 2020).

In this regard, many of us, out of necessity, have been using recent technologies such as Zoom to teach throughout the crisis, and already. We have come to trust the technologies, as tools, more or less (Zalmanson, 2020). The acceptance of online learning tools among instructors tends to occur far more readily among those in disciplines that rely less on unmediated experience and direct contact and interaction, such as the social sciences, than among those in higher-touch fields, where educational technologies are useful only to a certain point, and where the shift to virtual learning during the lockdown aroused no small amount of frustration. Yet, it seems uniquely suited to digital learning, attention issues which is something profound as being lost on a social level in its excessive lessonorientation, remain. Indeed, 'social distance learning,' has a certain hollowness, which can be depressing, so much so that I find myself waxing nostalgic, though I am far from 
sentimental, for the days when Zoom was an educational program for children on public television.

Finally, the Universities and schools closures due to the first wave of COVID-19 in early 2020 required specific consideration by all educational actors to achieve flexible learning approaches for all students through technology-enhanced learning. Therefore, the importance and challenges of using technology during the outbreak in Palestine has been discussed in this article.

The main challenges of implementing online education in Palestine as a response to COVID-10 crisis are the widening of the education' digital divide and an increasingly negative attitude towards online education. Nevertheless, this documentation of the COVID19 wave one highlights future opportunities as well as challenges for decision-makers, who can be expected to introduce further changes as they rethink the usefulness of integrating technology into education reform, not only for future waves of the pandemic, but also in the long term and on a large scale.

\section{Recommendations}

We would recommend the following steps to improve digital transformation in a university context:

- A clearly defined strategy for digital transformation is needed by Palestinian universities to pursue quality assurance.

- A digital transformation vision must be established and managed by leaders with this vision.

- Development of technical knowledge skills for teacher candidates should be carried out as a prerequisite for the transformation to complete the pre-service training in this direction.

- To determine the status of digital transformation strategies in Palestinian universities, it is feasible to provide the evaluation of the internal and external stakeholders, through quantitative and/or qualitative methods.

- The presence of the processes of instructional design among teachers in digital

\section{References}

Affouneh S, Salha S, Khlaif Z. (2020). Designing Quality E-Learning Environments for Emergency Remote Teaching in Coronavirus Crisis. Med Sci. 2020;11(2):1- 3. 10.30476/IJVLMS.2020.86120.1033

Balyer, A., \& Öz, Ö. (2018). Academicians' Views on Digital Transformation in Education. International Online Journal of Education and Teaching, 5(4), 809-830

Agamben, G., (1995). Homo sacer: Sovereign power and bare life. Stanford, CA: Stanford University Press.

Bozkurt, A., \& Sharma, R. C. (2020). Emergency remote teaching in a time of global crisis due to CoronaVirus pandemic. Asian Journal of Distance Education, 15(1), i-vi. https://doi.org/10.5281/zenodo.3778083

DePietro, A. (2020). Impact of coronavirus (COVID-19) on college tuition and finances. Forbes.

Retrieved

from https://www.forbes.com/sites/andrewdepietro/2020/06/02/impact-COVID-19tuition-finance/\#7103eed24b88

DeVaney, J., Shimshon, G., Rascoff, M. \& Maggioncalda, J. (2002). Higher ed needs a longterm plan for virtual learning. Harvard Business Review. Retrieved from https://hbr.org/2020/05/higher-ed-needs-a-long-term-plan-for-virtuallearning.

Emilio, A., Mariana-Daniela, G., Juan, I., Germán, R. (2020) Sustainable Management of Digital Transformation in Higher Education: Global Research Trends. Sustainability, (12), 1-24.

García-Peñalvo, F. J. (2020). Reference model for virtual education at face-to-face universities. Campus Virtuales, 9(1), 41-56.

Giroux, H. (2010). Bare pedagogy and the scourge of neoliberalism: Rethinking higher education as a democratic sphere. The Educational Forum 74 (3), 184-196. 
González-González, C. S., Infante-Moro, A., \& Infante-Moro, J. C. (2020). Implementation of E-proctoring in Online Teaching: A Study about Motivational Factors. Sustainability, 12(8), 3488.

Gros, B., \& Garcia-Peñalvo, F. J. (2016). Future trends in the design strategies and technological affordances of e-learning. In M. Spector, B. B. Lockee, \& M. D. Childress (Eds.), Learning, Design, and Technology. An International Compendium of Theory, Research, Practice, and Policy, (pp. 1-23). Switzerland: Springer International Publishing. doi:10.1007/978-3-319-17727-4_67-1

Hilbert, M. (2011). The end justifies the definition: The manifold outlooks on the digital divide and their practical usefulness for policy-making. Telecommunications Policy, 35 (8): 715-736. doi:10.1016/j.telpol.2011.06.012

Hobbs, T.D. \& Hawkins, L. (2020). The results are in for remote learning: It didn't work. The Wall Street Journal. Retrieved from https://www.wsj.com/articles/schoolscoronavirus-remote-learning-lockdown-tech-11591375078

Kaminskyi, O., Yereshko, Y. \& Kyrychenko, S. (2018). Digital transformation of university education in Ukraine: Trajectories of development in the conditions of new technological and economic order. Information Technologies and Learning Tools 64 (2), 128-136.

Khlaif, Z. N., \& Salha, S. (2020). The Unanticipated Educational Challenges of Developing Countries in COVID-19 Crisis: A Brief Report. Interdisciplinary Journal of Virtual Learning in Medical Sciences, 11(2), 130-134.

Kuzu, Ö.H. (2020). Digital Transformation in Higher Education: A Case Study on Stra-tegic Plans. Vysshee obrazovanie v Rossii- Higher Education in Russia. vol. 29, no. 3, pp. 9-23. DOI: https://doi.org/10.31992/0869-3617-2019-29-3-9-23

Loveless, A., Burton, J., \& Turvey, K. (2006). Developing conceptual frameworks for creativity, ICT and teacher education. Thinking Skills and Creativity, 1 (1), 313.

McHugh, M. (2011). UN declares internet access a human right. Digital Trends. Retrieved from https://www.digitaltrends.com/computing/un-declares-internet-access-ahuman-right/

Orellana, V., Cevallos, Y., Tello-Oquendo, L., Inca, D., Palacios, C., \& Rentería, L. (2019). Quality Evaluation Processes and its Impulse to Digital Transformation in Ecuadorian Universities. In 2019 Sixth International Conference on eDemocracy \& Government (ICEDEG), (pp. 338-343). IEEE.

Parlak, B. (2017). Dijital çağda eğitim: Olanaklar ve uygulamalar üzerine bir analiz [Education in Digital Age: An analysis on opportunities and practices], Süleyman Demirel University, Journal of Faculty of Economics and Administrative Sciences, 22(15), 1741-1759. Parvianinen, P., Tihi

Rapanta, C., Botturi, L., Goodyear, P., Guàrdia, L., \& Koole, M. (2020). Online university teaching during and after the Covid-19 crisis: Refocusing teacher presence and learning activity. Postdigital Science and Education, 1-23.

Shraim, K., \& Crompton, H. (2020). The Use of Technology to Continue Learning in Palestine Disrupted with COVID-19.

Sofer, O. (2020). Ha-academia le-an: Part 1, [Audio podcast] Retrieved from https://www.kan.org.il/ podcast/item.aspx?pid=17145.

Yuen, A. H., Park, J., Chen, L., \& Cheng, M. (2018). The significance of cultural capital and parental mediation for digital inequity. New Media \& Society, 20(2), 599-617.

Zalmanson, L. Prod., [Marciano, Y. for Kan; Presenter and Ed. Markovitch, G.]. (2020). Ha-academia le'an: Part 1, [Audio podcast] Retrieved from https://www.kan.org.il/podcast/item.aspx?pid=17145 